\title{
RETORISK DYD
}

\section{På vej mod en ny retorisk normativitet}

\author{
Carsten Madsen \\ Aarhus Universitet \\ retcm@cc.au.dk
}

\begin{abstract}
Artiklen er en kritisk diskussion af det metodiske og videnskabsteoretiske grundlag for den vidt udbredte skandinaviske retorikforskning og -praksis, der i næsten 30 år har bygget på Charlotte Jørgensen og Merete Onsbergs værk fra 1987, Praktisk argumentation, og på værkets anvendelse af og introduktion til Stephen Toulmins argumentmodel. Ud fra et definitorisk og et etisk perspektiv fokuserer artiklen særligt på den redelighedsnorm, der i Praktisk argumentation fremstilles som det væsentligste vurderingskriterium for god og dårlig argumentation. Som alternativ hertil viser artiklen endvidere, hvordan retorisk argumentation med fordel kan vurderes ud fra den grundlæggende sammenhæng mellem retorik og etik, som Aristoteles fremfører. Artiklen udgør således et originalt bidrag til moderne retorisk sprogforståelse, argumentationsteori, retorisk kritik og etik.
\end{abstract}

Siden den første udgivelse i 1987 har Charlotte Jørgensen og Merete Onsbergs Praktisk argumentation nydt en fortjent status som en populær lærebog, der har øvet en betydelig indflydelse på forskellige kritiske bestræbelser på at forpligte den offentlige debat på klart artikuleret argumentation. Værket har desuden spillet en central rolle i den pædagogiske indførelse $\mathrm{i}$ argumentation inden for mange forskellige uddannelser i kommunikation og retorik i Danmark, men først og fremmest har det dannet skole i form af en retorisk kritisk praksis, der netop er kendetegnet ved at samle sin opmærksomhed om det argumentative niveau af offentlig kommunikation og retorik. I værket introducerer og videreudvikler Jørgensen og Onsberg den i mange sammenhænge anvendte argumentmodel fra Stephen Toulmins The Uses of Argument fra 1958, og selv om forfatterne overfører modellen på "retorikkens tre klassiske appelformer hvorved man kan vinde tilslutning til et synspunkt: logos, etos og patos" (Jørgensen \& Onsberg 2008: 69), er den i sin analyse og vurdering af argumentation forankret i en normativ rationali- 
tetsopfattelse, der må siges at være karakteristisk for store dele af moderne argumentationsteori. Med andre ord forstår den retorisk kritiske praksis, der henter sin normativitet ud fra dette værk, argumentation på en argumentationsteoretisk og ikke en retorisk baggrund.

Jeg vil ikke her gå ind $\mathrm{i}$ en overordnet diskussion af den argumentationsteoretiske tradition, hvori Jørgensen og Onsberg indskriver sig, men tværtimod søge at forholde den nogle åbenlyse mangler set ud fra et retorisk perspektiv. Jeg vil imidlertid heller ikke gå dybere ind i en ellers påtrængt diskussion om forholdet mellem moderne argumentationsteori og retorik. Forståelsen af den indre sammenhæng mellem retorisk og dialektisk argumentation, der skriver sig tilbage til, men ikke udfoldes hos Aristoteles, er i moderne tid blevet et filosofisk anliggende langt fra den retoriske kritik, der interesserer os her. ${ }^{1}$ Derimod vil jeg ud fra de definitoriske manøvrer og bestemmende træk i den anbefalede normativitet diskutere dens etiske implikationer. Dette vil jeg gøre ved at kontrastere den argumentationsteoretiske normativitet med en retorisk-etisk normativitet med udgangspunkt i Aristoteles. I bund og grund hviler den følgende kritiske diskussion på en antagelse af, at der eksisterer flere væsensforskellige måder, hvorpå moderne retorik kan arve Aristoteles, eller måske snarere, ud fra en moderne retorisk rationalitet, kan rekonstruere Aristoteles. Hermed antydet, at de følgende henvisninger til Aristoteles ikke tilstræber en historisk rekonstruktion af hans tænkning, men under inspiration fra Edward Schiappa og på den moderne tænknings betingelser tilstræber en rationel rekonstruktion af elementer af Aristoteles' forståelse af sammenhængen mellem retorik og etik (cf. Schiappa 1990:).

\section{Redelighedsnormen som vurderingskriterium}

Inden for dansk retorisk kritik og kommunikationsteori synes Praktisk argumentation at have ført til en udbredt forståelse af "redelighed" som det væsentligste vurderingskriterium for bedømmelsen af argumentation, retorik og formidling. Værket gennemgår fire kriterier som grundlag for vurderingen af argumentation, hvor god argumentation fordres at være korrekt, effektiv, interessant og redelig. Heraf er de to første kriterier de mest almindelige, mens det interessante og det redelige angives som "afgørende for praktisk argumentation" (Jørgensen \& Onsberg 2008: 101). Dog medgiver forfatterne, at de to afgørende kriterier står i et spændingsforhold til hinanden, sådan at "det interessante [ofte er] uredeligt, og det redelige ofte kedeligt" (114). Uden at forandre den grundlæggende redelighedsnorm fremfører Jørgensen også i andre sammenhænge begrebet som afgørende vurderingskriterium for bestemmelsen af, hvad der karakteriserer den gode debattør, "hvilke krav man kan stille til redelig debat" (Jørgensen 1995: 31), og hvad der er god og dårlig retorik (cf. Jørgensen 2000: 39-40). I denne sammenhæng er det væsentligste imidlertid, at det kritiske spørgsmål om en argumentations redelighed indfører en etisk norm i den praktiske argumentation, uden at denne etiske dimension af retorikken dog gøres til genstand for en eksplicit refleksion.

Som etisk grundnorm bliver begrebet om redelighed grundigt uddybet i Jan Foght Mikkelsens Formidlingsetik (2002). Ligeledes anvender Mie Femø Nielsen og 
Christian Kock begrebet med henvisning til såvel Jørgensen og Onsberg som Mikkelsen i "Hvad er spin?" fra Politisk spin (2007). Derudover synes redelighed at fungere som underforstået grundnorm bag kritiske vurderinger i adskillige andre danske udgivelser, blandt andet i bestræbelsen på at forpligte politiske aktører i den offentlige debat på at fremføre "ordentlig argumentation" for fremsatte synspunkter (Kock 2011: 16). Samme norm ligger til grund for de "krav og kriterier", Kock stiller til "politikernes kommunikation til vælgerne" i artiklen "Fornuftig uenighed". Her slås der "til lyd for at en fordring om at svare redeligt på kritiske modargumenter og spørgsmål er central blandt disse krav" (Kock 2008: 66, min kursivering).

På trods af disse bidrag til en øget kritisk forståelse af og deltagelse i den offentlige debat, måske især politiske debatter, så er den grundlæggende præmis, redelighedsnormen, kun sparsomt blevet diskuteret. Den væsentligste kritik af redelighed som vurderingskriterium er blevet fremført i Christina Pontoppidans offentligt tilgængelige speciale i retorik ved Københavns Universitet, Er retorikken farlig? - er etikken? (2007), hvor redelighed fremstilles som en problematisk norm i forhold til et teknisk retoriksyn. Pontoppidan argumenterer for, at redelighedsnormen næsten kontraintentionelt bliver anvendt som et værn mod Aristoteles' forståelse af retorik som kunsten at finde "de mulige overbevisende momenter i ethvert givet stof” (Aristoteles 1983: 33, 1255b). Ligeledes har Anders Due fremført mindre kritikpunkter af redelighedsnormen i artiklen "Det var ikke med vilje" (2005).

I de sammenhænge, hvor redelighedsnormen anvendes, drejer det sig generelt om at etablere et kritisk grundlag for at bedømme retoriske og strategiske henvendelsesformer, der forsømmer sig mod redelighed ved i det skjulte at fungere som "løgn, fortielse eller fordrejning" (Jørgensen \& Onsberg 2008: 111) eller andre former for vildledning og manipulation af publikum. Redelighed fungerer typisk som et almengyldigt krav til den gode kommunikation uafhængigt af den retoriske situation. I Nielsen og Kocks definition er et redeligt udsagn forbundet med en intention om at sige det, "som kommunikatoren oprigtigt anser for rigtigt og retvisende" (Nielsen \& Kock 2007: 21). Talerens indstilling til at kommunikere er her afgørende, og den kan enten være redelig og give udtryk for det rigtige og retvisende, eller den kan være villig til at dreje eller 'spinne' et udsagn med henblik på "at stemme modtagerne på en ønskelig måde” (ibid.).

Når kritikeren anvender en fordring om redelighed med det sigte at forpligte taleren på at udtrykke sig i overensstemmelse med, hvad denne opfatter som rigtigt og retvisende, kan begrebet siges at sætte en pligtetisk normativitet. Ud over at fungere som en objektiv norm for kritikeren tjener fordringen således også som moralsk handlingsvejledning for taleren. ${ }^{2}$ Begrebet om redelighed sætter altså kritikeren i stand til at vurdere retorik eller argumentation som enten god eller dårlig, en tale der enten retleder eller vildleder sine tilhørere. Som fordring om ikke at lyve fungerer redelighed som en absolut kategori med universel gyldighed, og denne normativitet ugyldiggør hermed løgnen eller den bevidste vildledning som mulighed for taleren. Det drejer sig med andre ord om en almen moralsk lov baseret på en velafgrænset forståelse af, hvornår et udsagn kan siges at være sandhed eller løgn. 
Nielsen og Kock tilføjer ganske vist, at det at bringe nogen i vildfarelse, eller tale uredeligt, "ikke [er] det samme som at lyve, men er beslægtet med det" (Nielsen \& Kock 2007: 21). Dette forbehold betyder, at fordringen om redelighed ikke nødvendigvis angår alle elementer i en kommunikation, der ud fra strategiske hensyn for så vidt godt må være tendentiøs eller underlagt spin, men fordringen forpligter stadig taleren på helt overordnet at udtrykke sin "ærlige mening” (ibid.). Fordi den involverede etik ikke diskuteres nærmere, kan det være vanskeligt at afgøre, hvordan forfatterne tænker sammenhængen mellem løgn og ærlighed, og accepten af et vist mål spin kan derfor nemt opfattes som en gradbøjning af løgnen. Tilbage står imidlertid, at forfatterne knytter det etiske krav om redelighed til spørgsmålet om ærlighed, jf. også den idiomatiske sammenpasning af “ærlig og redelig”, men for kritikeren synes fordringen om redelighed altså at fungere som et universelt gyldigt krav om, at afsenderen ikke må lyve.

\section{Problemerne ved en negativ definition}

Vi behøver ikke at diskutere konkrete eksempler på anvendelsen af redelighed som vurderingskriterium for at se, at der er tale om et problematisk begreb, hvis definition vi er nødt til at overveje grundigt. Jørgensen og Onsbergs krav om redelig argumentation beror på en stipulativ definition, det vil her sige en regelgivende definition inden for praktisk argumentation, med udgangspunkt i den negative situation, hvor argumentationen forekommer uredelig. Dette gør det vanskeligt at vurdere, hvornår argumentation egentlig kan siges at være god. Vi må derfor sammenholde den stipulative definition med den leksikalske definition af redelighed for at få en bedre forståelse af, hvor og hvornår vi synes i stand til at afgøre, at vi har med redelig argumentation at gøre. Som jeg senere vil gøre gældende, kan dette imidlertid ikke afgøres inden for et strengt argumentationsteoretisk perspektiv, men kræver en anderledes retorisk forståelse, der inddrager den bredere etiske sammenhæng, hvorudfra først Aristoteles og senere Cicero og Quintilian forstår retorik og argumentation.

Den stipulative definition optræder hos Jørgensen og Onsberg, hvor redelighed overhovedet defineres som det, der ikke er uredeligt, og god argumentation bør altså undgå det uredelige. I afsnittet "Redelig argumentation" lyder den indledende bestemmelse:

Ved uredelig argumentation forstår vi argumentation hvor afsender søger at vinde tilslutning ved at bringe modtager i vildfarelse. Hvis man f.eks. gør tilslutningen afhængig af at modtager i situationen er ude af stand til at gennemskue argumentationen, har han misbrugt sit privilegium som afsender (Jørgensen \& Onsberg 2008: 110).

Fra første færd bliver redelig argumentation teoretisk defineret gennem det, den $i k k e$ er, og på intet tidspunkt fremsættes en realdefinition af redelighedens væsensbeskaffenhed. Den negative definition forsynder sig hermed mod den logik, i hvis tjeneste argumentationen netop er sat til at fungere. I genus-species definitioner som her, hvor det drejer sig om at bestemme det særlige (species) ved det gode 
argument (genus), som Jørgensen og Onsberg som sagt fordrer skal være korrekt, effektiv, interessant og redelig, er det en grundlæggende logisk regel, "at en definition ikke bør være negativ dér, hvor den kan være positiv" (Copi \& Cohen 1990: 154). Undtagelser fra denne regel gælder kun udelukkelsesbegreber, eller "excluders", der ikke lader sig definere positivt (cf. Hall 1959). ${ }^{3}$ Copi og Cohens indføring i logik er en ofte anvendt reference til forståelsen af definitioner, men også flere lærebøger i argumentation, for eksempel Trudy Goviers A Practical Study of Argument, regner det for fejl at opstille definitioner, der er for brede, for snævre, negative, tager udgangspunkt $i$ et definiendums accidens, anvender obskure termer eller er cirkulære (cf. Govier 2010: 75). ${ }^{4}$ Andre lærebøger i logik tilføjer desuden emotive og figurative definitioner som problematiske. Ifølge Ordbog over det Danske Sprog (ODS) bliver redelighed imidlertid rent leksikalsk defineret positivt, så der er ikke noget sprogligt belæg for Jørgensen og Onsbergs stipulative negative definition.

Under henvisning til udelukkelsesbegreber mener Mikkelsen ikke desto mindre at kunne godtgøre, hvorfor redelighed skal defineres negativt: "Nødvendigheden af at definere redelighedsbegrebet negativt skyldes selve begrebets logiske status" (Mikkelsen 2002: 77). Han overvejer først mulige synonyme definitioner af redelighed: " $\mathrm{fx}$ troværdighed, hæderlighed, fairness, sandfærdighed, rationalitet, objektivitet osv." (73), og han finder, at det engelske "fairness" kommer tættest på. Men så skriver han om redelighed:

Begrebet findes kun på dansk og tysk og betegner ifølge Ordbog over det Danske Sprog netop en handlemåde som "ikke rummer kneb, lumskhed og partiskhed” (jf. Nissen Kruuse 1991: 152). Bemærk at 'redelighed' defineres negativt som det der ikke betjener sig af kneb osv. (73-74).

Mikkelsen søger altså leksikalsk belæg for Jørgensen og Onsbergs stipulative definition, men han gør det ved at begå citatfusk. Den citerede henvisning til Helle Nissen Kruuses Etik i journalistik vedrører slet ikke ordet "redelighed", sådan som Mikkelsen får det til at lyde, men hun citerer derimod definitionen af ordet "fair" fra ODS. Han søger altså på et falsk grundlag at kvalificere Jørgensen og Onsbergs definition og konkluderer, at "redelighed [ikke kan] defineres positivt, men udelukkende negativt som alt det der ikke er uredeligt. [...] Redelighed er således [...] fravær af uredelighed!" På den baggrund definerer han "'uredelighed' som 'al uigennemskuelig argumentation og alle uigennemskuelige virkemidler som vildleder"” (77 og 78). Der er som sagt intet leksikalsk belæg for denne stipulative negative definition. ODS angiver tværtimod det, man inden for logikken kalder for "synonyme definitioner" med adskillige positive betydninger: "oprigtighed; ærlighed; retskaffenhed; retlinethed; tidligere ogs.: dygtighed; duelighed." Det er korrekt, at ODS anfører negative betydninger af adjektivet "redelig", når det anvendes om personer: "uden svig, lumskeri, forstillelse olgn.", men også her dominerer positive synonymer den leksikalske definition: "ærlig; oprigtig; især: ærlig, retskaffen, retlinet i sine handlinger, i sit forhold til andre mennesker; [...] paalidelig; solid, reel 
(især i pengesager); tidligere ogs.: dygtig, duelig olgn." Ligeledes fremhæves de idiomatiske sammenhænge: "have redelige hensigter" og “ærlig og redelig”. Den Danske Ordbog definerer også redelighed positivt og anfører synonymerne “ærlighed” og "oprigtighed”. Der er altså på ingen måde sprogligt belæg for den negative definition af den begrebslige og normative anvendelse af ordet redelighed.

Grundbetydningen af redelighed hidrører fra et sammenfald af to oprindeligt forskellige ord, dels en afledning af "rede" i betydningen at være klar til, i orden, til rådighed, klarhed etc., dels det plattyske "redelig" (jf. højtysk "redlich”), ærlig, forstandig, som igen er afledt af det plattyske "Rede", fornuft, tale (jf. det højtyske "Rede", tale). Disse nuancer rummer altså et vist betydningsfællesskab med det græske logos. Frem for at give anledning til en negativt bestemt normativitet som grundlag for en retorisk kritisk vurdering af det, der lader sig opfatte som uredelig argumentation, kunne redelighedsbegrebet inden for den beskrevne argumentationsteoretiske sammenhæng i realiteten have givet anledning til en positivt bestemt normativitet, så vi ved redelig argumentation forstod en argumentation, hvor afsender søgte at vinde tilslutning ved at anvende et for modtager klart og tydeligt sprog, der appellerer til modtagerens fornuft. Imidlertid ville dette begreb ud fra den her rejste kritik endnu være for snævert, idet retorisk argumentation nødvendigvis også må forstås ud fra appeller til ethos og pathos.

Problemet med den negative definition af redelig argumentation som en tale, der ikke vildleder eller manipulerer, er, at den gør det vanskeligt at vurdere, hvornår vi faktisk møder en redelig tale, en god og ærlig argumentation, som vi ikke behøver forholde os kritisk eller skeptisk til, men tværtimod kan føle os trygge ved at træde i dialog med og eventuelt lade os overbevise af. Er det kun, når argumentationen ikke er uredelig? Men, "en definition bør forklare, hvad en term betyder snarere end, hvad den ikke betyder" (Copi \& Cohen 1990: 154). Der er simpelthen alt for mange situationer, som forestillingen om redelighed og redelig argumentation ikke betegner, til, at en negativ definition på nogen måde kan dække dem. Alene en positiv definition tillader os at afgøre, om vi bør fatte tillid til en bestemt argumentation som redelig. Hvis det for eksempel er et spørgsmål om, at den redelige argumentation ikke må være løgn, så er der ud fra den vurderingshorisont, der opstilles i Praktisk argumentation, problemer forbundet med at afgøre, om taleren faktisk udtrykker sin ærlige mening. På samme måde vil dagligsprog, der kun sjældent kan underordnes et bivalensprincip, og ironiske udtryksformer være problematiske, fordi den angiveligt ærlige mening forbliver uudtalt. Hermed bevæger vi os over i en problematik, som Jørgensen og Onsberg selv er opmærksom på, idet de medgiver, at "eftersom vi forbinder redelighedskriteriet med afsenders intention og holdning til modtager, er bedømmelsen af en argumenterende teksts redelighed i særlig grad et fortolkningsspørgsmål” (Jørgensen \& Onsberg 2008: 114). Definitionen af god argumentation ud fra kriteriet om, at den ikke må bære uredelig, er altså ikke tilstrækkeligt vurderingsgrundlag, men kræver desuden en forudgående vurdering af den intention, hvormed et argument fremsættes, altså en overvejelse af afsenders ethos, men som markeret med begrebet "intention" for dem en overvejelse på et bevidsthedsfilosofisk grundlag. 


\section{Den analytiske begrænsning af redelig tale}

Der kan i den forbindelse være grund til at sammenholde den argumentationsteoretiske forståelse af argumentation i Praktisk argumentation med en mere retorisk forståelse af argumentation. I forhold til Aristoteles' skelnen mellem tre modeller for argumentation inden for henholdsvis analytik, dialektik og retorik synes Jørgensen og Onsberg fortrinsvis at placere sig i forlængelse af den dialektiske logik, der er karakteristisk for Toulmins argumentmodel. Ligesom den klassiske dialektik er også Toulmins forståelse af argumentation primært udviklet med henblik på at overveje etiske spørgsmål. Men det sandhedsbegreb, der synes at ligge til grund for deres kritiske vurdering af, om en argumentation beror på sandhed eller løgn, forekommer dog snarere knyttet til et analytisk ideal om, at det må kunne demonstreres, hvad der måtte være den sande fremstilling af en situation, eller hvad der måtte være intentionen bag en afsenders argumentation.

Det analytiske ideal om at argumentere ud fra en sand fremstilling af kendsgerninger og meninger (cf. Jørgensen \& Onsberg 2008: 111) omfatter ikke det kasuistiske i, at en situation, der kalder på retorik, er bestemt ved et konfliktfuldt forhold mellem stridende påstande. I et opgør med dette ideal, som han fører tilbage til Platon, bemærker Robert L. Scott, at "det tiltrækkende ved det analytiske ideal, der normalt kun bliver uklart forstået, men ikke desto mindre er stærkt virksomt i retorikken hos dem, der betragter sandhed som forudgående og bemyndigende, ligger i indsmuglingen af fornemmelsen af vished i menneskelige affærer" (Scott 1967: 12). Scott nævner videre, at argumentationsteorier, der trækker på Toulmin, typisk henholder sig til kapitel tre, "The Layout of Arguments", fra The Uses of Argument og dermed overser den større sammenhæng, hvor Toulmin skelner mellem analytiske og substantielle argumenter (cf. 10-12). Der hersker således en tendens inden for argumentationsteorier til at vurdere praktisk argumentation på baggrund af analytisk argumentation, der egentlig kun er gyldig for universelle sandheder, for så vidt sådanne overhovedet findes. Som Scott gør rede for, er substantielle argumenter, der er de væsentligste for Toulmin, omvendt karakteristiske ved at være underordnet en tidsfaktor, der gør deres sandhedsudsagn provisorisk.

I en mere retorisk forpligtet bestræbelse på at arve Aristoteles må man gøre gældende, at der jo netop anvendes retorisk argumentation dér, hvor vi ikke kan afgøre, hvad der er sandt. Retorik skal næppe heller forstås som et spørgsmål om gennem talen at gøre sandheden effektiv over for dem, der endnu ikke har erkendt den, men er altså snarere en måde at forholde sig erkendende på i en verden, hvor der ikke gives nogen sikker viden om, hvad der er sandt. Derfor beskæftiger retorik sig med det sandsynlige. Aristoteles viderefører i bearbejdet form det sofistiske begreb om det sandsynlige, eikos, det vil sige det "der forekommer for det meste", som udgangspunkt for "retoriske syllogismer" eller "enthymemer", hvor argumentationen "opbygges af sandsynligheder og tegn" (Aristoteles 1983: 38, 1357a). ${ }^{5}$ Det betyder, at argumentation ifølge den aristoteliske retorik ikke skal vurderes ud fra et kategorisk redelighedskriterium, fordi retorikken i de fleste tilfælde angår det, vi forholder os forhandlende til, og "det meste af hvad vi bedømmer og overvejer, kan jo også forholde sig anderledes; menneskenes rådslagninger og overvejelser angår 
nemlig det, de gør, og deres handlinger er alle af denne slags, praktisk talt ingen af dem [er] dikteret af nødvendighed" (ibid.). Uden at dette behøver føre til en relativisme, får det, som vi skal se, betydning for en anderledes udformet normativitet, der udstikker betingelserne for, hvad vi kan opfatte som god og dårlig argumentation.

En anden type problem i den teoretiske definition af redelighed er, at den skaber en forvirring af de aristoteliske bevismidler ved at gøre logos til den væsentligste appelform. Aristoteles er meget omhyggelig med at opregne bevismidlerne i en bestemt rækkefølge: ethos, pathos og logos, og han tilføjer, at "det er lige ved, at [talerens ethos] rummer det stærkest overbevisende moment af alle" (Aristoteles 1983: 34, 1356a). Men ved at fremhæve redelighed som et vurderingskriterium vedrørende sandhed, og altså fremstille god argumentation som sand tale, har logos forrang frem for de øvrige bevismidler. Mere paradoksalt er det imidlertid, at redelighedsnormen af Jørgensen og Onsberg fremstilles som et ethos-begreb, hvilket utvivlsomt er en korrekt fremstilling, men det får ingen konsekvenser for den involverede normativitet. Forfatterne udmønter fordringen om redelighed i en række krav til taleren i form af en åben, respektfuld, lydhør og anerkendende "holdning til modtager" (Jørgensen \& Onsberg 2008: 110, cf. også 115). Der fordres altså en bestemt kommunikativ adfærd, en bestemt karakter (ethos) hos taleren, hvorfor redelighed må siges at blive defineret som et ethos-begreb. Ikke desto mindre forpligter de dette etiske krav på en kritisk vurdering af den praktiske argumentation, hvor et logos-begreb får forrang, uden at kravet om redelighed på noget tidspunkt giver anledning til at diskutere talerens ethos.

Vi har altså her at gøre med en analytisk rationalitetsform, hvor appeller til logos dominerer over appeller til ethos og pathos. Det medfører for eksempel, at "stråmandsargumenter", hvor det på et analytisk grundlag kan demonstreres, at en modstanders argument gengives i forvansket eller svækket form, for at det derved nemmere kan affejes, vil blive vurderet som uredelige, fordi de forsynder sig mod den praktiske argumentations logisk funderede krav om sand tale (cf. Jørgensen \& Onsberg 2008: 85). ${ }^{6} \mathrm{Ud}$ fra samme rationale vil man være tilbøjelig til at afvise andre former for argumenter som fejlslutninger, for eksempel som argumentum ad hominem, hvor fokus flyttes fra sagen til manden, og argumentum ad verecundiam, hvor der henvises til autoriteter på et ufuldstændigt grundlag. Når logos på den måde har forrang, vil kritikeren ligeledes behandle appeller til publikums medlidenhed eller frygt som fejlslutninger, henholdsvis betegnet argumentum ad misericordiam og argumentum ad baculum. Ganske vist gør Jørgensen og Onsberg for deres part gældende, at "argumentation kan være redelig eller uredelig hvad enten den bevæger sig inden for logos, ethos eller pathos” (Jørgensen \& Onsberg 2008: 111), men det indbyrdes forhold mellem ethos, pathos og logos samt det retorisk-etiske forhold mellem redelighed som vurderingskriterium og bevismidlerne bliver aldrig underlagt en eksplicit refleksion.

I de retoriske situationer, hvor ethos, og dermed spørgsmålet om redelighed, faktisk "rummer det stærkest overbevisende moment af alle", sådan som det ifølge Aristoteles typisk vil være tilfældet, kan de såkaldt fejlsluttede argumenter sagtens 
være redelige. Det kan endda forekomme, at ad hominem argumenter i den forstand er de vigtigste, for de angår modpartens ethos og spørgsmålet, om vi overhovedet kan nære tillid til modparten, for eksempel når modparten hævder at sige sandheden. Mere afgørende åbnes der hermed op for nødvendigheden af at sammenholde retorik og argumentation med et mere nuanceret begreb om etik end det, der arbejder i det skjulte hos Jørgensen og Onsberg.

\section{Redelighedsnormens uerkendte etik}

Den måske væsentligste anke mod redelighedsnormen som vurderingskriterium må derfor også vedrøre dens implicitte etiske forestillinger, altså de moralfilosofiske positioner, der følger af den praktiske argumentation og formidlingsetikkens videnskabsteoretiske valg. Hvor kritiske vurderinger ud fra praktisk argumentation baserer sig på pligtetik, dér knytter formidlingsetikken an til en nytte- eller konsekvensetik. Mikkelsen vender sig direkte mod den måde, hvorpå Jørgensen og Onsberg anvender redelighedsnormen, fordi den ifølge ham er "sindelagsetisk", hvilket vil sige, at den henhører under en kantiansk eller deontologisk moralfilosofi, altså en pligtetik. Han mener, at praktisk argumentation lægger for stor vægt på afsenderens intention med sin kommunikation, og han forsøger på den baggrund at skabe et bredere råderum for redelighedsvurderinger: "En mere konsekvensetisk (og mindre sindelagsetisk) samt en mere modtagerorienteret (og mindre afsenderorienteret) beskrivelse af uredelighed bør derfor i højere grad indbefatte ikke-intenderet vildledning" (Mikkelsen 2002: 80). Mikkelsens redelighedsnorm bevæger sig altså over mod den moralfilosofiske position, der også betegnes utilitarisme, idet han søger at kombinere "pligt- og konsekvensetik, hvor konsekvenserne begrunder pligten" (72).

En retorisk kritik baseret på pligtetik vil fremhæve den tale som redelig, der fungerer i overensstemmelse med korrekte moralske påbud eller principper, for eksempel forbuddet mod at lyve eller ikke at udtrykke sin ærlige mening. En sådan normativitet er handlingsvejledende, og ud fra forudgående, fastsatte moralske regler vil den kunne forholde sig kritisk vurderende til, hvad der i en given situation principielt vil være korrekt at sige. Ifølge Kock kan dette for eksempel udmøntes i normsatte regler "til at kvalitetsvurdere den politiske debat fra borgernes synspunkt", hvor "politikernes argumenter ikke bør føre os bag lyset om fakta”, således "at vi ikke bliver fyldt med løgn eller misvisende fremstillinger af fakta, der udelader noget vigtigt og får os til at tro på ting som ikke er tilfældet” (Kock 2011: 12-13). Det bliver hermed også et vigtigt etisk anliggende for Kock at kunne holde politikerne ansvarlige for de begrundelser, de ifølge ham er forpligtet til at fremføre for deres synspunkter.

Ret beset forekommer dette ikke blot at være et rimeligt anliggende, men i en demokratisk sammenhæng også en særdeles vigtig funktion af retorisk kritik. Imidlertid vil jeg hævde, at kritikken af politisk retorik med fordel kan anvende en anderledes konstrueret normativitet, der i højere grad undersøger de etiske implikationer af politiske udsagn og politikernes ethos. Man får næppe politikerne til at holde op med at betjene sig af udsagn, der på et analytisk grundlag lader sig ud- 
lægge som løgn, fortielse eller fordrejning, men som jeg her søger at gøre gældende, er det givetvis en vigtigere retorisk kritisk opgave at vurdere, hvorvidt politikeres argumenter i situationen fremstilles på en indsigtsfuld, moralsk ansvarlig og tillidsvækkende måde. Dette ville være en kritik, der grundede sin normativitet på Aristoteles' ethos-forståelse, hvor netop disse tre kvaliteter fremstilles som tre ethos-dyder, hhv. betegnet phronēsis, aretē og eunoia, oversat som "klogskab", "moralsk karakter" og "velvilje" (cf. Aristoteles 1983: 113, 1378a). Vi vender tilbage hertil om lidt.

Den formidlingsetiske vurdering, der hviler på et konsekvensetisk grundlag, vil modsat en pligtetisk vurdering fremhæve den tale som redelig, der har størst nytte for flest mulig mennesker. Ifølge denne normativitet skal talen i mindre grad rettes ind efter abstrakte regler og i højere grad efter de praktiske konsekvenser, den eventuelt kan afstedkomme. I vurderingen af en tale vil spørgsmålet om redelighed være mere relativt og i højere grad tage hensyn til talens kontekst, det vil sige det aktuelle problem, tilhørerne og de retoriske vilkår for talen. Spørgsmålet om ansvarlighed skal derfor også forstås ud fra de konsekvenser, som en tale skønnes at have inden for konteksten, idet dette skøn etableres ud fra bredt accepterede moralske antagelser, modsat pligtetikken der i mindre grad vægter konteksten og i højere grad, om talen i logisk forstand er gennemskuelig og i klar overensstemmelse med en ærlig mening. Men fælles for pligt- og konsekvensetiske vurderinger af talen er antagelsen om, at der altid ligger generelle overvejelser bag vurderingerne, nemlig principperne for uredelig tale, som vi må have kendskab til for at kunne tale rigtigt og retvisende.

Den negative definition af redelighed har i begge tilfælde indflydelse på den involverede normativitet, idet der i overensstemmelse med begge former for etik postuleres universelle principper for den moralsk forpligtede tale, der først og fremmest ikke må være uredelig. Imidlertid diskuteres det ikke, hvorfor talen skal være redelig på de fremstillede betingelser, og sådan som den fremstillede moral påbyder det, eller hvordan dette påbud mere overordnet er motiveret og retfærdiggjort. Tilbage står det problem, at redelighed alene forpligtes på talens argumentation og ikke på ethos, ikke på talerens etiske eksempel. Men i mange retoriske situationer er det en forholdsvis overkommelig opgave for den uredelige taler at fremsætte en tilsyneladende redelig tale, fordi intentionen forbliver dunkel eller skjult. Derfor bør den afgørende kritiske vurdering også hvile på en ethos-analyse af, hvorvidt taleren gennem sin tale og i fremførelsen (actio) heraf udtrykker den fornødne phronēsis, aretē og eunoia, således at publikum sættes i stand til at opfatte taleren som tillidsvækkende.

I den pligtetiske normativitet for vurderingen af praktisk argumentation savner man desuden en eksplicitering af et distributivt retfærdighedsprincip, der fastsætter og forklarer de regler, redelighedsnormen pånøder den talende. Hos Jørgensen og Onsberg hedder det blot: "uredelig argumentation er $i$ sagens natur dårlig” (Jørgensen \& Onsberg 2008: 110, min kursivering). Redelighed er altså en selvindlysende grundnorm. ${ }^{7}$ Der henvises med andre ord til normative entiteter uden for og uafhongigt af den phronēsis, den praktiske fornuft, der i den retoriske 
situation vil gøre forskellige moralske konklusioner gældende. Problemet forbliver, at den tale, der virker redelig i ét perspektiv, kan virke uredelig $i$ et andet og vice versa, for der kan ikke gives nogen universel regel for redelig tale. Toulmin omtaler netop dette problem i sin diskussion af universelle præmisser, blandt andet med følgende bemærkning:

Praksis tvinger os til at anerkende, at generelle etiske regler højst kan tilstræbe at forblive gyldige i fraværet af effektive modargumenter: pligtkonflikter er et uundgåeligt træk ved morallivet. Hvor logik kræver formen 'Al løgn er forkastelig' eller ' $A l$ overholdelse af løfter er rigtigt', bliver det idiomatiske modsvar derfor 'At lyve er forkasteligt' og 'At holde løfter er rigtigt'. Logikerens 'al' bringer uheldige forventninger med sig, som i praksis ofte ikke kan undgå at blive skuffede. Selv de mest generelle hjemler i etiske argumenter risikerer i usædvanlige situationer stadigvæk at komme ud for undtagelser og kan derfor, selv ved fuld styrke, kun berettige til sandsynlige konklusioner (Toulmin 2003: 109).

Alligevel opstiller Jørgensen og Onsberg under henvisning til redelighed regelbundne krav og kriterier ud fra en betragtning om, at kommunikationsforholdet mellem afsender og modtager kan være enten symmetrisk eller asymmetrisk. Ansvaret for kommunikationen i en symmetrisk situation bestemmes som ligeligt fordelt, når afsender og modtager forekommer jævnbyrdige "med hensyn til magt, anseelse, viden o.a.” (Jørgensen \& Onsberg 2008: 110). I en sådan situation bærer modtageren "selv [...] en del af skylden" (110), hvis vedkommende lader sig forlede af uredelige argumenter. Derimod vurderes den asymmetriske situation, hvor afsender synes bedre i stand til at vildlede eller manipulere sin modtager gennem uredelig argumentation, at være direkte "farlig" og "uhyggelig" (111), ikke mindst hvis den i politisk sammenhæng antager form af demagogi. Den etiske fordring sigter mod at beskytte den svage part i kommunikationsforholdet, men uden at kunne give generelle hjemler for, hvornår og hvordan "afsender spekulerer i et asymmetrisk kommunikationsforhold" (111), sådan som kriteriet kræver det.

For denne skole af kritikere er det væsentlige i placeringen af ansvar og skyld for uredelig argumentation dog mindre den involverede etik og i højere grad den praktiske identifikation af de former, hvori den kan optræde. Såvel Jørgensen og Onsberg som Mikkelsen opstiller kataloger over udtryksformer, som kritikeren med fordel kan holde et vågent øje med. Jørgensen og Onsberg præciserer definitionen af uredelig argumentation som en argumentation, hvor "afsender søger at vinde tilslutning ved hjælp af løgn, fortielse eller fordrejning", og denne fordrejning bestemmer de desuden til at kunne optræde i form af "overdrivelse, forenkling og udskiftning" (Jørgensen \& Onsberg 2008: 111). Hertil føjer de en fordrejende argumentation, der har karakter af "syndebuk-argumentation" eller "eristik" (113). I hvert enkelt tilfælde pålægges afsenderen et personligt ansvar for ikke at fremføre uredelige argumenter, det vil sige en argumentation der ikke gør sig skyldig i at anvende sådanne udtryksformer. 
Det personlige ansvar i den etiske forpligtelse bestyrkes af, at forfatterne eksplicit forbinder redelighedsnormen "med afsenders intention og holdninger til modtager", hvor de dog samtidig medgiver, at det kan være vanskeligt "at dokumentere, hvad afsender har tænkt og villet” (113). Ikke desto mindre får afsender tildelt rollen som et frit, autonomt subjekt underlagt et moralsk imperativ om ikke at argumentere uredeligt. I overensstemmelse med pligtetikken får talen dermed ikke sin moralske værdi i kraft af sine eventuelle konsekvenser, men alene i kraft af de hensigter eller overvejelser, der ligger til grund for den. Uden at diskutere det forstår de hermed taleren som et etisk subjekt uafhængigt af den ethos, som taleren oparbejder i og med sin tale. Med andre ord tilsidesætter denne form for retorisk kritik talerens retorisk konstruerede ethos og henter sit kritiske vurderingsgrundlag uden for det retorisk særegne i situationen, og talen bliver hermed overvåget af et sæt moralske regler, der bestemmer, hvad der kan siges, og hvordan det skal siges.

Det er dette, jeg som sagt vil betegne en "substantiv moralsk realisme", det vil sige en metafysik, hvor normer for vurderinger hævdes at eksistere ubetinget i verden uafhængigt af den praktiske fornuft, der gør brug af dem. Heroverfor vil jeg i det følgende hævde, at retorisk kritik med fordel kan tage udgangspunkt i talerens diskursivt bestemte ethos, og at redelighedsnormen som vurderingskriterium i de hidtil analyserede sammenhænge afskærer muligheden for at lade talerens ethos få indflydelse på den kritiske vurdering af talen.

\section{Epieikeia som retorisk dyd}

Der kan næppe herske tvivl om, at spørgsmålet om redelighed er særdeles relevant at stille $\mathrm{i}$ forhold til retorik, argumentation og andre strategiske udtryksformer. Spørgsmålet drejer sig dybest set, om vi kan have tillid til den taler og den tale, der søger at bevæge os til at ændre vores handlinger og holdninger på ofte ganske væsentlige områder af vores liv. Sådan som begrebet fungerer i den analyserede sammenhæng, har det imidlertid kun status af det, man inden for moderne etik kalder et "smalt begreb", hvilket betyder, at det kun gives en nominel definition. Redelighed må være en mere omfattende retorisk dyd, men vi har kun fået udstukket dens generelle område og savner "en fuld eller "bred" definition af dyden" (Nussbaum 1988: 35). ${ }^{8}$ En "smal", nominel definition af redelighedsnormen forstår alene argumentationens etiske implikationer ud fra, hvad der på et analytisk grundlag lader sig bestemme som god eller dårlig, rigtig eller forkert argumentation. En "bred" definition kunne åbne op for en mere nuanceret diskussion af, hvad der i retorisk sammenhæng kan betragtes som en klog, retfordig, modig eller mådeholden argumentation. Især bliver spørgsmål om retfærdighed og rimelighed vigtige i en mere etisk forpligtet vurdering af retorisk ethos.

En sådan definition kan man finde hos Aristoteles, men udviklet på helt andre etiske vilkår end dem, vi hidtil har set redelighedsbegrebet forbundet med. I lyset af moderne dydsetik, der siden slutningen af 1950erne er blevet et kritisk alternativ til pligt- og konsekvensetik, vil jeg derfor i det følgende søge at reaktualisere elementer af den aristoteliske etik, sådan som den synes at kunne have betydning også for moderne retorik. Jeg hævder ikke at foretage en historisk rekonstruktion af for- 
holdet mellem retorik og etik hos Aristoteles, men søger derimod ud fra en konstitutiv opfattelse af retorik at fastholde visse af de diskursive momenter af dette forhold, sådan som de kan give anledning til en anderledes forståelse af redelighedens betydning for retorik.

Det er velkendt, at Aristoteles giver overlappende bestemmelser på de færdigheder, han mener tilhører det praktiske liv, når han gør rede for statskunst, etik og retorik. Fælles for statskunst, etik og retorik er, at de er rettet mod "agathon", det gode, men udfoldet som det, der er godt for "polis", bystaten. Det gøres nemlig gældende, at "de største dyder [selvsagt må] være dem, der gavner andre mest" (Aristoteles 1983: 69, 1366b). I den forbindelse finder vi imidlertid et aristotelisk begreb, der modsvarer det dansk-tyske redelighedsbegreb. Det er begrebet "epieikeia", der kan gengives med korrekt, passende optræden, retsindighed, rimelighed, jævnfør "fairness", altså et synonym for redelighed.

Aristoteles udvikler hovedsageligt sin teori om epieikeia i kapitel tretten og femten af første bog i Retorik og i kapitel ti af femte bog i Den Nikomacheiske Etik. I den danske oversættelse af Retorik gengives begrebet (blandt andet) med "billighed", hvilket kan forklares ud fra følgende citat fra ODS: "Staar der ingen Ting i Loven om det, saa er der da en Slags Ret og Billighed til”. Det stemmer overens med Aristoteles' definition af begrebet som en "retfærdighed ud over den skrevne lovs rammer" (Aristoteles 1983: 95, 1374a), altså en højere form for retfærdighed. Begrebet anvendes i samme betydning i Etikken, her oversat med "rimelighed" (Aristoteles 2009: 142, 1137a-b). I en diskussion af forholdet mellem rimelighed og retfærdighed tilføjer Aristoteles, at epieikeia er en slags retfærdighed, dog ikke retfærdighed i henhold til loven, men derimod "en korrektion af det lovfæstet retfærdige" $(143,1137 b)$. Både det retfærdige og det rimelige er gode, det rimelige kan endda erstatte det gode (agathon), og når de begge er gode, er de for så vidt "identiske", men "det rimelige er bedst" (ibid.), fordi den dyd, der er i stand til at korrigere loven, må gå ud over loven. ${ }^{9}$

Både i Retorik og Etikken anvendes begrebet imidlertid i en anden, men endnu væsentligere betydning, i Retorik i forbindelse med de indledende bestemmelser af bevismidlerne, ethos, pathos og logos. ${ }^{10}$ Aristoteles giver begrebet en menneskelig iklædning som "ho epieikēs", den rimelige eller fuldt afbalancerede person. Denne personificering af begrebet svarer til den, han giver "phronēsis", klogskab eller praktisk fornuft, der besiddes af "phronimos", det praktisk vidende menneske. Han er interesseret $\mathrm{i}$, om de praktiske færdigheder, herunder de retoriske, fungerer $\mathrm{i}$ overensstemmelse med en dydig adfærd, og derfor finder der i hans praktiske filosofi hele tiden en vurdering af handlende og talende personer sted, idet han kommenterer, hvilke personer der bør roses, og hvilke der bør dadles. De dyder, Aristoteles på den måde afkræver den gode retoriker, opsummerer Amélie Rorty under henvisning til phronimos i egenskab af overtalende person [Persuader]:

[Han] må ikke blot være i stand til skarpsindigt at tage bestik af en jury eller en Forsamling, idet han siger de rette ord på det rette tidspunkt og på den rette måde, han skal også gøre det for den rette årsag, for de rette mål, som et 
udtryk for enheden af sine intellektuelle og karaktermæssige dyder (Rorty 2011: 733).

Til forståelse af den grundlæggende etiske normativitet i retorikken forekommer det på den baggrund mindre vigtigt at vurdere et udsagn som argumentation og langt vigtigere at vurdere den fremstillede karakter (ethos) hos den person, der fremfører udsagnet, både for på et teknisk niveau at vurdere, hvor godt taleren fremfører det (rette ord, rette tidspunkt, rette måde), og for på et dydsetisk niveau at vurdere, om taleren fremfører udsagnet med det gode for øje (rette årsag). Vigtigst synes her at være, at det i etisk forstand gode styrer den tekniske færdighed, at alene den moralsk gode mand kan blive en dygtig taler, sådan som det ofte udtrykkes under henvisning til Quintilians citat fra Cato den Ældre: "vir bonus dicendi peritus", det vil sige en god mand, der er øvet i at tale (Quintilian 1958: 355). ${ }^{11}$ Imidlertid fremgår det også hos Aristoteles, at den, der for sine tilhørere fremstår som god i moralsk forstand, gør det i kraft af tekniske, diskursive færdigheder. Troværdighed hos en taler, siger Aristoteles, "afstedkommes ved talen selv og ikke af nogen forhåndsindstilling om, hvad slags menneske taleren er" (Aristoteles 1983: 34, 1356a.) ${ }^{12}$ Det vil sige, at evnen til at tale godt konstituerer taleren som et godt menneske, hvilket ikke er det samme som at vore et godt menneske. Dette er der ikke nødvendigvis noget moralsk betænkeligt ved, når man påtænker, at retorik først og fremmest skal vurderes på, om den forekommer god for samfundet (polis).

I retorisk sammenhæng bliver Aristoteles' væsentligste krav således, at talen gør det muligt for tilhørerne at opfatte den talende som "ho epieikēs", et anstændigt, retfærdigt og rimeligt menneske, sådan som han videre udtrykker det i den centrale definition af ethos som det første af bevismidlerne:

Overbevisning skabes gennem talerens [ethos], når talen holdes på en sådan måde, at den gør talerens person troværdig. Vi stoler nemlig mere og med større beredvillighed på, hvad anstændige mennesker [epieikēsi] siger, og dette gælder generelt i alle situationer, men aldeles afgjort dér, hvor der ikke foreligger vished, men er levnet plads for tvivl. Denne virkning må imidlertid afstedkommes ved talen selv og ikke af nogen forhåndsindstilling om, hvad slags menneske taleren er. Vi er nemlig ikke enige med visse lærebogsforfattere, der ikke regner talerens [rimelighed, gr.: epieikeia] med som en del af det fagmæssige ud fra en forestilling om, at den ikke skulle bidrage til troværdigheden af det, der bliver sagt. Tværtimod: det er lige ved, at hans [ethos] rummer det stærkest overbevisende moment af alle (Aristoteles 1983: 34, 1356a).

Det er tydeligvis talens rent diskursive forhold, der konstituerer talerens troværdighed, og det rimelige, anstændige menneske, ho epieikēs, som tilhørerne fatter tillid til, er et produkt af talen. Taleren fremstiller med sin tale sig selv som taler, med de tilhørende karaktertræk og dyder, ved at udnytte talens fremstillende "virkning", ligesom også talerens "rimelighed" (epieikeia), der udgør grundlaget for at frem- 
bringe ethos i tilhørernes opfattelse, alene beror på effekter fremkaldt af talen selv. ${ }^{13}$ Denne centrale placering af epieikeia i Aristoteles' Retorik knytter værket tæt sammen med Etikken på en måde, der bør genovervejes nøje i forhold til moderne retorik. Samtidig er den med til at understrege den fremtrædende plads blandt bevismidlerne, som ethos har over for logos og pathos. Aristoteles bemærkning om, at ethos nærmest er "det stærkest overbevisende moment af alle", har fået flere kommentatorer til at udlægge ethos som styrende i forhold til bevismidlerne. ${ }^{14}$

\section{En ny normativitet}

I modsætning til den redelighedsnorm, jeg har problematiseret, er epieikeia som vurderingskriterium ikke afhængig af en instans uden for talen selv i form af et etisk subjekt eller universelle præmisser, men derimod af, om selve talen er vellykket. Det indebærer, at sandhedsproblematikken her ser væsentlig anderledes ud, idet det med talen snarere drejer sig om at sandsynliggøre den fremstillede eller konstituerede virkelighed som sand end om at henvise til en angiveligt sand virkelighed, som om den eksisterede på den fremstillede måde uafhængigt af talen.

Selv hvis taleren angiveligt spiller et falskspil ved i den retoriske situation at fingere eller påtage sig en falsk ethos, dvs. en ethos der ikke synes i overensstemmelse med den etiske habitus, som taleren ville have udvist i andre sammenhænge uafhængigt af den retoriske situation, så ville det ud fra et dydsetisk perspektiv være en forfejlet kritik at afvise den anvendte retorik, hvis den ellers formåede at overbevise sit publikum. Den kritiske opfattelse af en retorik som et falskspil kræver jo et neutralt ståsted, hvorfra kritikeren vurderer den, men dette ståsted modsvarer på ingen måde, hvad der finder sted i den retoriske situation. Det publikum, der i situationen lader sig overbevise af en sådan 'falsk' taler, vil ikke være ført mere bag lyset eller forledt af vildledende argumenter, end de fremførte argumenter vil være fremsat inden for rammerne af etiske dyder, som publikum nødvendigvis må kunne genkende som overensstemmende med sine egne standarder for god etik. Ellers ville en persuasio, en retorisk motiveret overtalelse og overbevisning, ikke kunne opstå. Den taler, der fremstår som anstændig og redelig i publikums øjne, fremtræder altså som et eksempel på netop den klogskab, dyd og velvilje, som det konkrete publikum i et givet samfund almindeligvis vil værdsætte. Taleren bekræfter disse ethos-dyder hos sit publikum ved at fremtræde som et eksempel på dem, og det er inden for de etiske rammer, der udstikkes heraf, at talerens argumentation overhovedet fungerer, dvs. virker som de sandsynligvis mest hensigtsmæssige og bedste argumenter i den pågældende sag. Det er i den forstand, at god retorik er den, det gode menneske fremfører, og den gode handling er den, det gode menneske udfører eller, i en retorisk situation, advokerer. ${ }^{15}$

En retorik på dette dydsetiske grundlag er derfor heller ikke direkte handlingsvejledende på samme måde, som en pligtetisk kritik ville fordre. Sådan som den gode tale konstruerer taleren som "ho epieikēs", der sætter tilhørerne i stand til at tillægge ham ethos, fremstår han som udstyret med de fornødne dyder på en måde, hvor han virker eksemplarisk for tilhørerne. Dyden er eksemplarisk eller forbilledlig, ikke vejledende, hvilket betyder, at den retoriske motivation her beror på, 
at tilhørerne føler sig overbeviste af og kan identificere sig med den fremstillede taler, fordi de deler talerens opfattelse og fremstilling af, hvad en dydig person er. Taleren kan altså henvise til og argumentere for, hvad der forekommer at være epieikeia, rimelighed, i en given situation, men det er for så vidt endnu vigtigere, at taleren gennem sin ethos selv fremstår som eksempel på eller rollemodel for det rimelige, det mest retfærdige at gøre i en given sammenhæng.

Retfærdighed er den vigtigste dyd i den antikke såvel som i store dele af den moderne dydsetik, og den bliver også det centrale vurderingskriterium ifølge denne normativitet, der bygger videre på Aristoteles' forståelse af sammenhængen mellem retorik og etik. Det kritiske grundspørgsmål til retorik drejer sig derfor om, hvorvidt taleren fremstiller det retfærdige på en for tilhørerne overbevisende måde: hvem taler? Det er sådan, Aristoteles spørger, men langt senere er det også sådan, Nietzsche spørger. En moderne retorisk kritik kan med fordel begynde med en genovervejelse af dette spørgsmål.

\section{Litteratur}

Aristoteles (2009). Etikken (5. udg.), Det Lille Forlag. Aristoteles (1983). Retorik, Museum Tusculanums Forlag.

Copi, I.M. \& C. Cohen (1990). Introduction to Logic (8. udg.), Macmillan Publishing Company.

Due, A. (2005). Det var ikke med vilje, Rhetorica Scandinavica, nr. 34: 17-34.

Eggs, E. (1999). Ethos aristotélicien, conviction et pragmatique moderne, i: Amossy, R. (red.), Images de soi dans le discours. La construction de l'ethos, Delachaux et Niestlé.

Govier, T. (2010). A Practical Study of Argumentation (7. udg.), Wadsworth.

Hall, R. (1959). Excluders, Analysis, vol. 20, nr. 1: 1-7.

Harris, E.M. (1994). Law and Oratory, i: Worthington, I. (red.), Persuasion: Greek Rhetoric in Action, Routledge.

Harris, E.M. (2004). Le role de l'epieikeia dans les tribunaux athéniens, Revue historique de droit français et étranger, vol. 82, nr. 1: 1-13.

Harris, E.M. (2013). How Strictly Did the Athenian Courts Apply the Law? The Role of 'Epieikeia', Bulletin of the Institute of Classical Studies, vol. 56, nr. 1: 27-48.

Horn, C. (2006). Epieikeia: the competence of the perfectly just person in Aristotle, i: Reis, B. (red.), The Virtuous Life in Greek Ethics, Cambridge University Press.

Isokrates (1986). Om formuebytning, i: Fire taler, Museum Tusculanums Forlag.

Jørgensen, C. (1995). Debattens væsen og uvæsen. Om fjendtlighed i offentlig debat, Retorik studier, nr. 10: 3-43.

Jørgensen, C. (2000). Hvem bestemmer hvad der er god retorik? Vurderingsinstanser i normativ retorik, Rhetorica Scandinavica, nr. 15: 34-48.

Jørgensen, C. og M. Onsberg (2008). Praktisk argumentation (3. udg.), Nyt Teknisk 
Forlag.

Kock, C. (2008). Fornuftig uenighed, Rhetorica Scandinavica, nr. 48: 64-83.

Kock, C. (2011). De svarer ikke. Fordummende uskikke $i$ den politiske debat, Gyldendal.

Kock, C. (2012). Ordets magt. Retorisk tonkning der holder, bd. 1: Før 1900, Samtidslitteratur.

Korsgaard, C.M. (1996). The Sources of Normativity, Cambridge University Press.

Kruuse, H.N. (1991). Etik i journalistik. Forlaget Ajour.

Madsen, C. (2016). Retorik og lykke. Arven fra Aristoteles og græsk eudaimonisme, Kultur og klasse, 121: 45-61.

Meyer, M. (2004). La Rhétorique, PUF.

Meyer, M. (2008). Principia Rhetorica. Une théorie générale de l'argumentation, PUF.

Mikkelsen, J.F. (2002). Formidlingsetik. Bidrag til en etik om strategisk massekommunikation, Roskilde Universitetsforlag.

Nielsen, M.F. \& C. Kock (2007). Hvad er spin?, i: Høybye, A. et al. (red.), Politisk spin, Akademisk Forlag.

Nussbaum, M.C. (1988). Non-Relative Virtues: An Aristotelian Approach, Midwest Studies in Philosophy, vol. 13, nr. 1: 32-53.

Pontoppidan, C. (2007). Er retorikken farlig? - er etikken? En kritisk diskussion af den etiske redelighedsnorm (Københavns Universitet), http://www.kommunikationsforum.dk/file.asp?id=3690.

Quintilian (1958). Institutio Oratoria, bd. 4, bog XII, Loeb Classical Library.

Rorty, A. (2011). Aristotle on the Virtues of Rhetoric, The Review of Metaphysics, vol. 64, nr. 4: 715-33.

Schiappa, E. (1990). Neo-Sophistic Rhetorical Criticism and the Historical Reconstruction of Sophistic Doctrines, Philosophy and Rhetoric, vol. 23, nr. 3: 307-15.

Scott, R.L. (1967). On Viewing Rhetoric as Epistemic, Central States Speech Journal, nr. $18: 9-17$.

Toulmin, S.E. (2003). The Uses of Argument (rev. udg.). Cambridge University Press.

1 I La Rhétorique (2004) og Principia Rhetorica (2008) udvikler Michel Meyer under henvisning til en "problematologi" en fundamental lov for enheden mellem retorisk og dialektisk argumentation, idet han viser, hvordan retorik forstået som disciplin og dialektik forstået som procedure anvender to forskellige, men komplementære former for rationalitet, der står i forbindelse med hinanden.

2 I etisk henseende er redelighed med andre ord ikke at forstå som et kasuistisk begreb, hverken i klassisk forstand eller i Toulmins moderne udformning. Redelighed anføres af Jørgensen og Onsberg som et kriterium, der er gyldigt for alle tilfælde af god argumentation, og der eksisterer for dem ingen gode grunde til at fremføre en usand argumentation, hvad der faktisk eksisterer som mulighed inden for Toulmins kasuistiske udgangspunkt i "good reasons".

3 Eksempler på negative definitioner er det græske ord "barbar”, der oprindeligt betyder en ikkegræker eller en dårligt, utydeligt talende person, eller ordet "ungkarl”, der betegner en voksen mand, som ikke er eller har været gift. 
4 I forbindelse med den definerende fase af argumentationens dynamik anfører Jørgensen og Onsberg, at man skal passe på, "at [definitionen] ikke bliver for bred, at den ikke bliver for snover, og at den ikke kører i ring” (Jørgensen \& Onsberg 2008: 41), men de nævner intet om negative definitioner.

5 Senere i Retorik angiver Aristoteles fire slags præmisser for enthymemerne: "det sandsynlige (to eikos), eksemplet (paradeigma), det tvingende indicium (beviset, tekmerion) og det almindelige indicium (semeion)" (191, 1402b).

6 Kock fremstiller i femte kapitel af De svarer ikke konsekvent stråmandsargumenter som "løgn", cf. følgende eksempel: "Når Sandy Brinsk hævder at justitsministeren "siger" sådan og sådan, er det en usandhed sagt mod bedre vidende - kort sagt, en løgn" (Kock 2011: 97).

7 Normativiteten fungerer som en "substantiv moralsk realisme”, hvor svar på moralske spørgsmål findes, "fordi der gives moralske fakta eller sandheder, hvorom disse spørgsmål stilles” (Korsgaard 1996: 35).

8 Jeg oversætter Nussbaums hævdvundne betegnelser for etiske definitioner som enten "thin" eller "thick" med "smal" og "bred".

9 Begrebet "epieikeia" har en lang historie i folkelige, filosofiske og juridiske sammenhænge, og i moderne tid er det hovedsagelig blevet diskuteret i forhold til den juridiske praksis i antikken (Harris 1994, 2004 og 2013). I retorisk sammenhæng kan man også finde en anden betydning af ordet som stil-begreb hos Hermogenes, hvor det gerne oversættes som "beskedenhed" (cf. Kock 2012: 117).

10 Cf. Horns artikel "Epieikeia", hvor han viser sammenhængen mellem de to betydninger af begrebet som et teknisk ideal, der sætter én i stand til at dømme i vanskelige sager, og som et personligt ideal, der udtrykker et i etisk henseende fuldstændig afbalanceret menneske. Horn konkluderer her: "Det der virkelig gælder for Aristoteles er det personlige ideal at have en perfekt karakter" (Horn 2006: 165).

11 Quintilian skriver videre: "[taleren skal] frem for alt besidde den kvalitet, Cato sætter først [...], han skal være et godt menneske".

12 Denne bestemmelse viser en vigtig forskel fra Isokrates' behandling af samme problematik, idet han betoner "det bedst mulige renommé" hos "vel anskrevne personer" forud for talen, mens Aristoteles betoner den ethos, som talen gør det muligt for tilhørerne at tillægge taleren (cf. Isokrates 1986: 192).

13 De tre ethos-dyder, som talen skal frembringe hos taleren, og som er de "tre ting, der gør, at en taler virker overbevisende", bestemmer Aristoteles som sagt som "hans klogskab [phronēsis], hans moralske karakter [aretē] og hans velvilje [eunoia]" (Aristoteles 1983: 113, 1378a). Som alle andre steder, hvor talerens ethos diskuteres, indgår også i denne sammenhæng overvejelser om "epieikēs", her oversat med "reelle" og sidestillet med dyden (aretē).

14 Cf. Ekkehard Eggs, der på et højere niveau lader ethos (forstået som den menneskelige karakter) samle ethos, pathos og logos (forstået som de retorisk-tekniske bevismidler) under sig. "Man kunne også sige, at ethos konstituerer en specifik fortcetning af disse tre områder. [...] kun den taler, der i sin diskurs formår at udvise de højeste grader af ethos i disse tre områder - phronèsis, aretē, eunoia vil reelt overbevise" (Eggs 1999: 47). Gennem de tre bevismidler skal den menneskelige karakter (ethos) således demonstrere at være i besiddelse af de tre ethos-kvaliteter, idet aretē fremkommer gennem ethos, eunoia gennem pathos og phronēsis gennem logos.

15 Cf. min artikel "Retorik og lykke”, hvor jeg viser, hvordan Aristoteles i Retorik fastsætter spørgsmålet om det gode (agathon) som styrende for argumentation for det hensigtsmæssige eller nyttige (sumpherontos) på en måde, hvor den retoriske aktivitet underordnes det etiske mål om lykke (eudaimonia) (Madsen 2016: 46-48). 